\title{
Peter Wad
}

\section{Komparation \\ i kritisk realistisk \\ perspektiv}

Kritisk realistisk videnskabsfilosofi frembyder et nyt enhedsvidenskabeligt perspektiv for sociologisk forskning. Artiklen undersøger, om dette perspektiv kan bidrage til en videreudvikling af sociologisk komparation. Selvom komparative metoder har høj status i kritisk realistisk sociologi, har man paradoksalt nok ikke leveret en ny komparativ metodik. Man henviser til den eksisterende metodelære på feltet, dvs. til en tradition med rødder tilbage til John Stuart Mill's induktive metodik fra 1843! Er det acceptabelt? Og er der noget at hente $\mathrm{i}$ denne tradition, hvis man stadig finder det relevant at formulere en genuin kritisk realistisk komparativ metodik i en verden under globalisering? 
$\mathrm{F}$ ormålet med artiklen er at diskutere, om og i givet fald hvordan kritisk-realistisk videnskabsfilosofi kan bidrage til videreudviklingen af komparation som sociologisk metodik?

Kritisk realisme repræsenterer et videnskabsteoretisk perspektiv, der forholder sig kritisk til såvel positivismen som hermeneutikken samtidig med, at den søger at integrere 'stærke' sider af begge tilgange $i$ en ny enhedsvidenskabelig filosofi (Wad 2000a, 2000b). Som denne videnskabsfilosofi kendes i dag, er den især formuleret af Roy Bhaskar og en kreds omkring ham (Archer et.al 1998). Siden midten af 1990erne er den for alvor blevet lanceret i svensk sociologi (Djurfeldt 1996, Danermark mfl. 1997). Nyhedsværdien af kritisk realisme betvivles dog også (Johansson \& Lind 1999), men det sker ud fra den lidt defaitistiske tro, at der intet nyt er under himlen - en opfattelse, der grundlæggende strider mod den kritisk realistisk virkelighedsopfattelse, hvor man opererer med emergens, dvs. fremkomsten af objekter med nye strukturer, kræfter og mekanismer!

Artiklen starter med en præsentation af kritisk realisme, hvor den ontologiske argumentation går forud for epistemologiske og metodologiske overvejelser ${ }^{1}$. Det første hovedspørgsmål er, om kritisk realisme formulerer et nyt grundlag for sociologisk forskning, hvor komparationen indgår som en central metodik? Hvordan må den sociale virkelighed være beskaffen for, at en kritisk realistisk komparation er mulig? Og hvilke principper bør denne komparative metode forfølge? Den første paradoksale konstatering er, at komparation har høj prioritet i kritisk realistisk sociologi, men at man her trækker på eksisterende komparative metodikker uden at underkaste dette metodearsenal en kritisk realistisk vurdering.

Det næste hovedspørgsmål er derfor, om eksisterende komparative metodikker indfrier de videnskabsfilosofiske krav til en kritisk-realistisk orienteret komparation? For at besvare disse spørgsmål gennemgår artiklen kortfattet den dominerende komparative tradition, der har rødder i efterkrigstidens empirisk-analytiske samfundsvidenskab og John Stuart Mill's klassiske induktive metodologi fra $1843^{2}$. Kvalitativ komparativ analyse (Ragin 1987) samt nyere komparativ politisk økonomi (Janoski \& Hicks 1994) vurderes særskilt, da de repræsenterer to nyere bestræbelser på at integrere kvalitative og kvantitative komparative metodikker. Denne gennemgang munder ud i den anden paradoksale konstatering, at den komparative tradition ikke rummer en komparativ metodik, der indfrier kravene til en kritisk-realistisk metodologi.

Da hverken den dominerende komparative tradition eller kritisk realistisk sociologi kan levere en acceptabel komparativ metodologi, rejser der sig et tredje hovedspørgsmål: Er det muligt og stadig relevant at udvikle en kritisk realistisk komparativ metodologi ud fra elementer af den eksisterende komparative metodik, når man samtidig tager vore dages internationalisering og globalisering af sociale systemer i betragtning? Artiklen konkluderer, at såvel Charles Ragin's kvalitative komparative metodik som Janoski \& Hicks metodestrategi kan reformuleres på en sådan måde, at vigtige krav til kritisk realistisk komparation kan imødekommes.

\section{Kritisk realisme}

Kontroversen mellem idealisme og realisme går langt tilbage i såvel videnskabsfilosofiens som sociologiens historie, hvor den blandt andet optræder i form af modstillingen mellem objektivisme og subjektivisme. Denne modstilling har splittet sociologien i en overvej- 
ende positivistisk og hermeneutisk hovedstrøm.

Kritisk realisme forsøger at syntetisere modsætningen i en form for dialektisk forståelse af relationen mellem det subjektive og det objektive: Vores viden om verden er begrebs- og teoriafhængig, men den er hverken determinerende for verden eller determineret af verden. Vores verdensbillede er ikke identisk med verden, og verdenen er ikke identisk med vores erfaringer om den. Der er forskel på vores subjektive opfattelse af verden og verdenen uden for os selv. Djurfeldt (1996) kalder denne grænse for den perceptuelle Berlinmur, og den er ikke faldet sammen, selv om Berlinmuren er det. Kritisk realisme kritiserer således positivistisk forskning for at begå den såkaldte 'epistemiske fejltagelse', der består i, at man sætter lighedstegn mellem vores erfaring om verden og selve verdenen. Denne fejlslutning kendetegner en naiv form for realisme, hvor man arbejder ud fra en 'flad' ontologi om verden, dvs. at verden er, som den fremtræder.

I modsætning til den naive realisme opererer kritisk realisme med et 'dybt', differentieret og stratificeret verdensbillede (ontologi): empiriens domæne (erfaringer); det faktiske domæne (begivenheder og erfaringer); og realitetens domæne (mekanismer, begivenheder og erfaringer) (Bhaskar 1998:41). Empiri afspejler således kun toppen af isbjerget (det 'synlige'). Der vil være en lang række begivenheder, som er faktisk eksisterende men ikke erfarede, og der vil være en uendelig række af skjulte objekter med kræfter og mekanismer, der genererer begivenheder, eller som ophæver hinandens effekter, eller bare er 'inaktive'.

Blandt kritiske realister er der bred enighed om, at hovedformålet med forskning er at øge kendskabet til de generative mekanismer, der skaber den faktiske verden (Danermark 1997: 235). Men be-

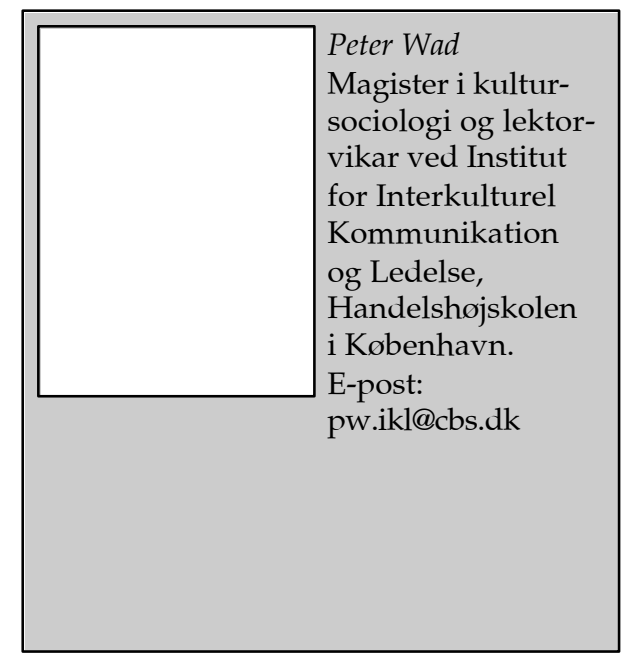

skaffenheden af den virkelighed, der studeres, er forskellig fra natur- til samfundsvidenskab. Verden og med den videnskaberne om verden er stratificerede i den forstand, at deres genstandsfelter antager en stigende grad af kompleksitet, når vi bevæger os fra fysik via biologi til human- og samfundsvidenskaberne. Nye generative mekanismer opstår og skaber dermed nye kausale dynamikker (emergens-princippet). Skabelse af viden gennem læreprocesser og bevidst handlen ud fra denne viden (rationel adfærd) kan også løfte det sociale liv op på et nive$\mathrm{au}$, hvor fornyelsesprocessen institutionaliseres, og historiens gang bliver dermed uforudsigelig.

Sayer (1992 [1984]) går så vidt, at han mener, at det empiriske domæne er et realt domæne i den forstand, at bevidstheden om en given virkelighed udgør en generativ mekanisme. Han reducerer dermed de tre domæner til to og begår dermed en fejltagelse, der med Margaret Archer's terminologi kunne kaldes 'conflation' (sammenpresning, forkortning af virkeligheden). Men denne fejltagelse kan overvindes ved en forlængning af den sociale virkelighed, idet man kan opfatte erfaringer som nødvendige forudsætninger for viden, motivation og be- 
vidst handlen. Derved kan vi både adskille erfaringer (det empiriske domæne) fra motivation (det reale domæne) og efterfølgende relatere dem til hinanden: Erfaringer anskues som forudsætninger for generative bevidsthedsmæssige mekanismer, og disse mekanismer ses som forudsætninger for erfaringsdannelse. En sådan fortolkning ligger på linie med Archer's bærende princip (analytisk dualisme), som hun udfolder ikke mindst i sin redegørelse for forholdet mellem social struktur og social handlen (agency) (Archer 1995).

Det kritisk-realistiske årsagsbegreb er et generativt og kontekstuelt begreb, dvs. at det forklarer et fænomen (begivenhed Y) ud fra et sæt generative mekanismer, der er bundet til et objekts struktur (de indre relationer mellem objektets elementerne), og hvis virkninger er betinget af en given situationsbestemt kontekst. Konteksten består af historiske og aktuelle virkninger af det givne systems generative mekanismer, men denne kontekst er dynamisk foranderlig og åben, dvs. at den består af en mere eller mindre tilfældig sammenhobning af kræfter og begivenheder. Det er en kerneantagelse i kritisk realistisk ontologi, at alle virkeligheder (fysiske såvel som biologiske og human-sociale) principelt set er åbne systemer, dvs. at de indbefatter en (uendelig) mængde objekter/strukturer med generative mekanismer, der interagerer på (uendelig) mange måder under (uendelig) forskellige vilkår.

Denne ontologi indebærer epistemologisk og metodologisk set, at man forkaster den empirisk-analytiske videnskabs søgen efter generelle lovmæssigheder og dennes logiske sideordning af forklaring (kausalitet) og forudsigelse (prædiktion). I det kritisk realistiske verdensbillede kan man nemlig ikke finde universelle lovmæssigheder for komplekse og kontekstuelle fænomener. Og man kan ikke forudsige bestemte hændelser i åbne systemer, selvom man har fundet frem til forklaringen af det studerede objekts struktur. Kun hvor det er muligt at lukke et åbent system, dvs. ved at eliminere alle uvedkommende kræfter, kan man tilnærmelsesvis studere enkelte isolerede generative mekanismer.

Bhaskar's pointe er, at naturvidenskabens fremskridt netop skyldes mulighederne for at gennemføre det kontrollerede eksperiment, hvor man både kan producere (og variere) årsagen og kontrollere (neutralisere) virkningen af alle mulige andre relevante årsags-mekanismer. Dermed kan man isolere årsag og virkning og med høj grad af sikkerhed etablere en kausal relation. Man producerer (genererer) så at sige virkningen. Desuden kan man foretage prædiktioner, fordi man kan gentage forsøget under de samme kontrollerede forhold. I det kontrollerede eksperiment bliver prædiktion og forklaring i praksis to sider af samme sag (kausalitetsrelationen) , og prædiktionen kan fungere som en test af forklaringen (hypotesen og indirekte af teorien).

Det empirisk-analytiske falsifikationsbegreb duer imidlertid ikke inden for et kritisk realistisk univers af åbne systemer. Her siges en teori at være 'praktisk adekvat' når man kan afprøve den eksperimentelt (i et lukket system), og den desuden viser sig at passe (Djurfeldt 1996:6061). Derfor er det en kæmpe udfordring i kritisk realisme, at årsagsanalyse så at sige forudsætter lukkede systemer, mens den virkelighed, den omhandler, er åben og uforklarlig i sin mangfoldighed, foranderlighed og emergens. Da teori kun kan forankres empirisk i tids- og stedbegrænsede forhold, vil den altid være transitiv (forbigående), hvorimod de mere grundlæggende generative mekanismer opfattes som intransitive (blivende). Dog skiller samfundet sig ud fra naturen, idet generative sociale mekanismer 
er mindre intransitive end naturens. Det skyldes, at sociale strukturer og aktiviteter gensidigt betinger hinanden samtidig med, at social fornyelse er mulig blandt andet gennem menneske- og samfundsskabte lære- og innovationsproces.

Erkendelsesprocessen inden for human- og samfundsvidenskaberne er alt $i$ alt underlagt særdeles vanskelige vilkår, set ud fra et kritisk realistisk perspektiv. Virkeligheden er kompleks og kontekstuel, den kan være transfaktuel uden at være faktuel, den kan være faktuel uden at være erfaret eller erfaringsbar. Den rummer begivenheder, men de danner ikke evige regelmæssigheder eller lovmæssigheder. I Archer's (1995) forstand undergår den sociale virkelighed en 'elaborering' gennem social interaktion, dvs. at dens strukturer enten reproduceres eller transformeres over tid, hvilket igen elaborerer betingelserne for fremtidig interaktion.

\section{Komparation inden for kritisk realistisk sociologi}

Hvordan opfattes komparativ metodik da i et kritisk-realistisk perspektiv, hvor man primært fokuserer på at afdække generative mekanismer bag de begivenheder, man ønsker af forklare og forstå? Hvordan indgår denne metodik i forskningsprocessen inden for en kritisk realistisk sociologi? Hvad går den kritisk realistiske komparation ud på?

Ray Pawson, der sammen med Andrew Sayer (1992) hører til de mest metodologisk orienterede kritiske realister, foreslår følgende fremgangsmåde inden for sociologisk forskning (Pawson 1989:213):

- $\quad$ Formuler en forklaring af den empiriske sammenhæng (regelmæssighed), der ser sammenhængen som en effekt af en generativ mekanisme;

- $\quad$ Specificer den sociale kontekst, in- den for hvilken en given mekanisme opererer;

- Kontroller så vidt muligt for effekten af andre generative mekanismer.

Det er værd at lægge mærke til, at Pawson beskæftiger sig med regelmæssigheder (samvariationen mellem variablene ' $x$ ' og ' $y$ '). Dermed prioriterer Pawson på linie med positivistisk videnskab det rekurrente som videnskabens egentlige domæne, men kritisk realisme åbner op for at forklare såvel rekurrente som unikke begivenheder. Pawson forklarer regelmæssigheden ved at sammenkæde den afhængige faktor (explanandum, ' $y$ ') med den uafhængige faktor (explanans, ' $x$ '). I anden ombæring søger han at kontekstualisere denne sammenhæng, da konteksten (andre mekanismers virkninger) betinger, om ' $x$ ' aktiveres og bliver virkningsfuld (genererer ' $y$ ') eller ej.

Opstillingen af en kritisk-realistisk forklaring (hypotese eller teori) er dog mere kompliceret end i den empiriskanalytiske videnskab, idet man ikke primært søger at forklare observationer, men de transfaktiske generative mekanismer bag de faktiske begivenheder, som observationerne indikerer. Man fraskriver sig ikke nødvendigvis den induktive eller deduktive fremgangsmåde, som anbefales i empirisk-analytisk metodologi (Danermark mfl. 1997:171). Man lægger derimod afgørende vægt på den transcendentale abstraktionsproces til besvarelse af det grundlæggende spørgsmål: Hvad konstituterer et givet socialt fænomen? Denne abstraktionsproces består primært af to analysemetoder: abduktion og retroduktion.

Nogle betragter disse to begreber som mere eller mindre synonyme (Charles S. Pierce jf. Kirkeby 1990:123), mens andre (som Danermark et.al. 1997:134) betoner deres forskellighed. Danermark mfl. (1997) definerer 'abduktion' som: "En 
slutledning eller tankeoperation som innebär att en enskild företeelse eller händelse tolkes utifrån en upsättning av generella idéer, et tänkt sammanhang eller mönster" (1997:309), og 'retroduktion' som: "En tankeoperation som innebär att man konstruerar de grundläggande villkoren för att något skall vara vad det är" (1997:311).

De anerkender, at abduktion og retroduktion i forskningsprocessen let sammenblandes, men de understreger, at man med abduktion omfortolker noget til noget andet (gennem begrebslig rekontekstualisering), mens man med retroduktion argumenterer sig fra noget (empiriske observationer) til noget andet (transfaktiske mekanismer) (Danermark mfl. 1997:151-152). De lægger afgørende vægt på den retroduktive analyse i kritisk realistisk forskning, eftersom den inkluderer den transcendentale analyse, der er konstituerende for denne videnskabsfilosofi. Med transcendental analyse søger man bagom de erfarede begivenheder (det empiriske domæne) for at finde disse begivenheders generative mekanismer i det reale domæne.

Den retroduktive analyse's betydning for empirisk forskning (inklusiv komparative studier) er ikke helt åbenbar. Da man antager, at de transfaktiske mekanismer inden for den sociale virkelighed manifesterer sig faktuelt gennem deres virkning, implicerer det, at de kan studeres på det faktiske virkelighedsniveau, når de er operative. Ud fra det empiriske virkelighedsniveau må vi altså forsøge at abstrahere os til de generative forklaringer, der er operative på det faktuelle niveau, og derefter konkretisere forklaringen til det empiriske fænomen. Men dermed kan vi ikke direkte empirisk validere relationen mellem årsag og virkning, og vi står tilbage med håret $\mathrm{i}$ postkassen.

Pointen er, at årsag og virkning skal søges inden for en struktur (relationer mellem dele af et objekt) og denne strukturs konditionering ud fra virkningerne af andre objekters strukturer. Danermark mfl. (1997:61-63) fortolker denne strukturanalyse på den måde, at sociale kræfter/mekanismer/tendenser er bundet op på sociale objekters strukturer, dvs. deres relationer. Disse relationer kan være formelle (f.eks. klassifikatoriske) eller substantielle (reelle, virkningsfulde). De substantielle relationer kan igen opdeles $\mathrm{i}$ interne relationer, der er nødvendige (generativt kausale) for, at objektet eksisterer, og eksterne relationer, der er unødvendige (tilfældige) for eksistensen af det objekt, der studeres. Og denne differentiering kan kun fastlægges empirisk, fastslår Danermark mfl. (1997:62)!

Danermark-gruppens fortolkning anlægger ikke nogen entydig fortolkning på forholdet mellem strukturanalysen og den kontekst, objektet er indlejret i. I Archer's struktur-aktør analyse bliver strukturen således til 'kontekst' for aktøren og aktørens handlinger til 'miljø' (kontekst) for strukturens 'elaborering' (Danermark mfl. 1997:101). Heroverfor skal jeg præcisere, at konteksten her opfattes som relationer, der har indflydelse på aktiveringen/blokeringen af objektets strukturelle kræfter og mekanismer, men ikke på selve objektets struktur. Konteksten består således af situationsbestemte, forbigående, varierende eller tilfældige betingelser, der skyldes andre objekters effekter. Konteksten er derfor relevant $\mathrm{i}$ forklaringen af objektets faktiske ageren, men ikke for dets reelle (strukturelle) beskaffenhed. Endelig kan der være tale om flere kausale relationer, der knytter an til forskellige strukturer. Alt i alt kræver en tilbundsgående forklarende analyse, at de generative forklarende relationer kortlægges i deres kontekst samt at andre irrelevante forhold elimineres.

Det er i dette arbejde med at eliminere irrelevante faktorer og afdække de gene- 
rative mekanismer i deres kontekst, at Pawson ser relevansen og vigtigheden af komparative forskningsdesign eller forløbsundersøgelser:

\begin{abstract}
Since the physical and statistical elimination of these confounding mechanisms is out of the question, some kind of comparative or longitudinal research design is called for in order to at least recognize their action. Between them, these strategies can approximate what I have characterized as the realistic pincer strategy of achieving closure by matching mechanisms to environmental conditions (Pawson 1989:213).
\end{abstract}

Pawson (1989:219) går så vidt, at han slår til lyd for en markant opvurdering af komparative og longitudinale design i sociologiske undersøgelser. Danermark mfl. (1997 kap.5) er mere mådeholdne. De påpeger, at retroduktionen ikke i sig selv angiver en metode til at identificere de nødvendige generative mekanismer $\mathrm{i}$ virvaret af andre mekanismer, betingelser og tilfældigheder, men de fremhæver dog fem 'stærke' metoder som alternativer til det klassiske eksperiment (Danermark mfl. 1997:158-159): Kontrafaktisk tænkning; sociale eksperimenter; studier af patologiske tilfælde; studier af ekstreme cases; samt komparative case-studier. Disse metoder ligner til forveksling flere af de såkaldte 'informerede' casestudie designs (Flyvbjerg [1991] 1992:150), og de rummer alle komparativ metodik $i$ analytisk eller teoretisk forstand, dvs. at man enten sammenligner casene med hinanden eller med en fælles teori (Bonnel 1980:165).

I Danermark's forstand (1997:164165) kan komparative case-studier bidrage med et empirisk underlag for retroduktion. Det sker ved at vælge en række forskellige cases inden for forskningsfeltet og så gennem sammenligning identificere de fælles forhold, der relaterer sig til det fænomen, man ønsker at forklare. Disse fælles egenskaber (eller sæt af egenskaber) bliver omdrejningspunkt for den transfaktiske argumentation.

Denne udlægning indikerer for mig at se et første 'komparativt' paradoks: kritisk realistisk samfundsforskning anser komparativ metodik for at være særdeles relevant og nødvendig, men man har ikke udviklet en selvstændig metodologi på kritisk realistisk vis! Det ser endda ud til, at kritisk realistiske sociologer antager, at det komparative metodiske arsenal uden videre kan accepteres og bruges inden for et kritisk-realistisk perspektiv. Men kan det det?

\section{Kritisk realistisk metodologi}

Svaret på det spørgsmål afhænger selvfølgelig af de metodekrav, der kan og bør anlægges inden for kritisk realistisk sociologi. Disse krav er ikke entydigt formulerede og konkretiserede, og det er nok også mere end man kunne forvente. Danermark mfl. (1997:165) kritiserer ligefrem kritiske realister for ikke at have udviklet alternative forskningsdesigns til det klassiske eksperiment, når man nu kritiserer det så heftigt for at være uanvendeligt i den åbne verden, som specielt samfundsvidenskaberne bakser med. Gruppen (1997 kap. 7) tilslutter sig i denne situation en kritisk metodisk pluralisme. Denne metodologi inkorporerer eksisterende metoder fra positivistisk og hermeneutisk videnskab, og man tilstræber, at det sker i en kritisk realistisk orienteret forskningsproces og videnskabsteoretisk fortolkningsramme. Dermed søger man at bruge dem komplementært i forhold til de specifikke forskningsproblematikker, som hver tilgang sigter på at løse i forbindelse med problemformulering, bestemmelse af forskningsobjekter 
og deres strukturer, forskningsstrategi, anvendelsesmuligheder og begrænsninger.

Danermark-gruppens kritisk realistiske metodeovervejelser er inspireret af Andrew Sayer's skelnen mellem intensive og ekstensive forskningsstrategier (Danermark mfl. 1997 kap. 7; Sayer 1992 chap. 9). Det overordnede formål ('erkendelsesinteressen') med en kritisk realistisk sociologisk undersøgelse er at fastslå, hvad der genererer (producerer) en specifik social hændelse. Problemstillingen vil i forskningsmæssig forstand derfor altid rumme et krav om at identificere de generative mekanismer og deres samspil, der er nødvendige (og tilstrækkelige?) for at forklare det konkrete sociale fænomen, man ønsker at forstå. Denne problemstilling kan imidlertid kun varetages med den såkaldte 'intensive' forskningsstrategi, hvor man leverer en processuel, dynamisk forklaring af et eller nogle få cases. Den såkaldte 'ekstensive' strategi fokuserer på de sociale regelmæssigheder og fordelinger inden for genstandsfeltet, og den rummer derfor deskriptive undersøgelser af totale eller repræsentative udsnit af de sociale enheder inden for genstandsfeltet.

Danermark-gruppen argumenterer med Sayer, at den intensive strategi studerer substantielle relationer, mens den ekstensive strategi afdækker formelle relationer. Til trods for at de kausale substantielle strukturer har primat over de formelle kategorier, ser de dog i højere grad de to strategier som komplementære (1997:236 note 9). Ifølge Danermarkgruppe (og undertegnede) giver Sayer i praksis forrang til den intensive forskningsstrategi: Sayer (1992:246) koketterer med komplementaritetsopfattelsen, men hele hans argumentation slår på den ekstensive strategis manglende forklaringspotentiale, og det er jo hvad det drejer sig om, når det kommer til stykket.

Når kritisk realistiske metoder skal muliggøre en afdækning af generative årsagsforklaringer til faktiske sociale begivenheder og fænomener i åbne sociale systemer, må komparationen derfor kunne analysere sociale objekter i deres kompleksitet og kontekstualitet (Danermark mfl. 1997:233). For det første skal den kunne afdække substantielle generative relationer til forskel fra formelle (tilsyneladende eller tilfældige) relationer i deres kontekst. For det andet skal den kunne identificere substantielle (virkningsfulde) årsagsrelationer og differentiere mellem interne (nødvendige) relationer og eksterne (konditionelle) relationer. De eksterne konditionelle relationer udgør konteksten, mens de interne relationer udgør de generative mekanismer, der er relevante i forhold til den aktuelle problematik. Derfor må en kritisk komparativ metodologi integrere den retroduktive forklaringsproces, dvs. en kontekstuel generativ kausal analyse af de spørgsmål, som problemformuleringen rejser.

I udfoldet forstand kan komparativ metodik indgå i fire mulige metodologi-

\section{Figur 1: Typologi over komparative metodologier, bestemt efter komparationens dybde og kompleksitet.}

\begin{tabular}{|l|l|l|l|}
\hline \multicolumn{2}{|c|}{} & \multicolumn{2}{|c|}{ KOMPARATIONENS KOMPLEKSITET } \\
\cline { 3 - 4 } \multicolumn{2}{|c|}{} & \multicolumn{1}{|c|}{ Kontekstfri } & Kontekstafhængig \\
\hline $\begin{array}{l}\text { KOMPARA- } \\
\text { TIONENS } \\
\text { DYBDE }\end{array}$ & Substantiel & Type 3 & Type 4 \\
\cline { 2 - 4 } & Formel & Type 1 & Type 2 \\
\hline
\end{tabular}


ske grundtyper, opdelt efter 'dybden' i deres analyse af objektet (formelt/substantielt) og analysens kompleksitet (kontekstfri/kontekstafhængig) (figur 1):

Denne komparative typologi indfanger to afgørende kontroverser i komparativ makrosociologi: For det første modstillingen af nomotetisk, variabel forskning og ideografiske case studier (Goldthorpe 1997), der igen refererer til spørgsmålet om lukkede system - over for åbne system analyser. For det andet modstillingen mellem henholdsvis synkrone, 'udvendige' og statistiske analyser over for diakrone og dynamiske analyser, der igen refererer til spørgsmålet om klassifikatoriske, formelle relationer over for generative, substantielle relationer.

Den 'efterlyste' kritisk realistiske komparation inden for samfundsvidenskaben udgøres af type 4 (den dybe, komplekse komparation), mens det teoretisk forklarede naturvidenskabelige kontrollerede eksperiment hører under type 3. Type 2 kan bestå af historiske eller antropologiske, kvalitativt orienterede case studier, men såfremt de er enkeltstående i tid og sted kvalificerer de ikke som komparative studier. Type 1 inkluderer synkrone, kvantitativt anlagte samfundsvidenskabelige studier.

Hvilken type komparation(er) er det $\mathrm{da}$, at kritisk realistiske sociologer kan henvise til? Og kan de betegnes som kritisk realistiske komparative metoder (type 4)?

\section{Den dominerende komparative tradition}

John Stuart Mill's 'eksperimentelle' metodologi (1862 [1843]:425-448) indgår som et centralt grundlag for vigtige komparative metodikker af nyere dato inden for tværnational komparativ sociologi (Przeworski \& Teune 1970; Pennings et.al. 1999:43), historisk sociologi (Skocpol \& Somers 1980:183), kvalitativ kom- parativ analyse (Ragin 1987:12,36) og nyere komparativ / historisk analyse (Janoski \& Hicks 1994:13-17). Mill omtaler fem komparative metoder for kausalanalyse:

- Sammenfaldsmetoden (Method of Agreement), dvs. sammenligning af en række tilfælde for at identificere de faktorer, hvor der er sammenfald.

- Afvigelsesmetoden (Method of Difference), dvs. sammenligning af tilfælde, der afviger fra hinanden på netop det forhold, der ønskes undersøgt, men ellers ikke afviger fra hinanden på alle andre måder.

- Den indirekte afvigelsesmetode (Indirect Method of Difference, or Joint Method of Agreement and Difference), der kombinerer adskilte undersøgelser af henholdsvis sammenfald og 'frafald'.

- Restmetoden (Method of Residues), hvor man kender forklaringen på alle forhold i en række tilfælde undtagen et restforhold af faktorer (antagen årsag-virkning).

- Samvariationsmetoden (Method of Concomitant Variation), hvor man varierer graden af årsag/virkning, men ikke kan eliminere hele årsagen eller virkningen.

Disse fem metoder kan reduceres til to grundtyper: Sammenfaldsmetoden og Afvigelsesmetoden. Den indirekte afvigelsesmetode er sammenfaldsmetoden brugt to gang i komplementære tilfælde; samvariationsmetoden er en tillempning af afvigelsesmetoden, hvor man kun kan variere årsag-virknings-relationen kvantitativt og ikke kvalitativt; og restmetoden er afvigelsesmetoden, baseret på deduktive forklaringer af udfaldet, undtagen det 'uforklarlige' der så forklares af den årsag, der ikke indgår i deduktionerne.

De to grundmetoder bygger begge på eliminering ${ }^{3}$. Begrænsningen i rest- 
metoden består i, at den kun kan anvendes i eksperimentelle (kontrollerede) situationer, dvs. hvor man kender alle årsager og deres virkninger og således kan isolere resten og rest-forklaringen. Sammenfaldsmetoden er utilstrækkelig til at afsløre flere hver for sig tilstrækkelige årsager, da den kun kan identificere de nødvendige faktorer, der sameksisterer med virkningen, men eliminerer faktorer, der hver i sær er tilstrækkelige til at fremkalde virkningen. Dermed bliver afvigelsesmetoden og samvariationsmetoden de eneste korrekte metoder. Samvariationsmetoden lider dog under, at man ikke kan undersøge situationer, hvor årsagen slet ikke er aktiveret, og afvigelsesmetoden har den strenge forudsætning, at det undersøgte objekt er identisk fra situation til situation undtagen hvad angår årsag og virkning, dvs. det forudsætter en kontrolleret, eksperimentel situation. Den indirekte afvigelsesmetode er kun en tilnærmelse hertil, idet observationerne af de positive og negative årsagsrelationer foregår adskilt, og man kan ikke påregne fuldkommen overensstemmelse.

Mill betragtede sammenfaldsmetoden som en slags forundersøgelsesmetode til den egentlige undersøgelse, baseret på afvigelsesmetoden (1862 Vol. $\mathrm{I}: 433)$. At afvigelsesmetoden ikke kunne bruges rent (under kontrollerede betingelser) i samfundsforskning ('moralvidenskaben'), gjorde det faktisk umuligt at bedrive videnskab i egentlig forstand inden for dette område.

Sammenfattende kan man sige, at Mill's komparative metodik bidrager med metoder til analyse af det empiriske niveau. Den sigter mod at opstille og afprøve generelle lovmæssigheder omkring den faktiske virkelighed, hvor der sættes lighedstegn mellem empiri og fakticitet (den epistemiske fejltagelse). Kontekstualiseringen af årsagsforklaringer søges bevidst udraderet. Der opereres ikke ud fra en dyb virkelighedsopfattelse, hvilket umuliggør transcendental analyse af årsagsforhold. Samlet set svækker det udviklingen af kontekstuelle generative forklaringer på grundlag af komparativt materiale. Denne kritik rammer også alle de metodikker, der bygger på Mill's komparative metodologi, herunder de fire nedenstående:

1. Przeworski \& Teune (1970) opstillede to komparative strategier, der så at sige spejlvender Mill's komparative logik: 'the most different systems design', og'the most similar systems design' ${ }^{\prime}$. Pennings et.al. (1999:47) trækker trådene tilbage til Mill's metodik på denne måde:

- Most Different Systems design => Method of Agreement

- Most Similar Systems design => Method of Difference

2. Den komparative metodik for makro-sociologiske analyser blev videreudviklet af Theda Skocpol og Margaret Somers (1980). De skelner mellem tre komparative historiske metoder, hvor de to er inspireret af Mill's komparative logikker (Skocpol \& Somers 1980: 183):

- 'parallel demonstration af teori' (Mill's Sammenfaldsmetode):

- $\quad$ 'kontekstuel kontrastering' (Mill's afvigelsesmetode? ${ }^{5}$ );

- 'makro-kausal analyse' (Mill's indirekte og direkte afvigelsesmetode) Skocpol \& Somers sammenbygger de tre komparative metodikker i en forskningscyklus, der bider sig selv i halen: Parallel komparation med dens generaliserende teoridannelse efterfølges af kontrasterende komparation, der begrænser denne teori og identificerer alternative forklaringer. Disse forklaringer kan så undersøges gennem makro-analytisk komparation, hvorved man får en stær- 
kere kausalitet efterprøvet, men på et begrænset empirisk felt. Derfra går vejen videre til at søge teoriens gyldighedsområde udstrakt via den parallelle komparation. Da processen er cirkulær, kan man starte hvor som helst, men omvendt vil det også være svært at stå af, når karrusellen først er i gang. Skocpol \& Somers mener, at de hermed har kombineret de forskellige metoders styrke og minimere deres svaghed.

3. Charles Ragin's (1987) kvalitative komparative metodik er en udbygget version af Mill's grundmetoder: samstemmighedsmetoden og afvigelsesmetoden. Ragin bruger Boole's logiske algebra til at systematisere og formalisere metodikken (se næste afsnit). Derved bliver Ragin i stand at kombinere kvalitative casestudier og kvantitative variabel-studier samt integrere dem ved brug af konfigurationsbegrebet, dvs. at et socialt fænomen består af et kompleks af konkrete samvirkende faktorer. På de præmisser bliver Ragin i stand til at foretage komparative analyser af multikausalitet ud fra multi case studier.

4. Janoski \& Hicks $(1994: 7-13,17)$ foreslår en integration af Ragin's metodik med en række nyere kvantitative metoder (tidsstudier; 'pooled' metodik; 'event history analysis'), der rækker tilbage til Mill's samvariationsmetode og benytter sig af statistiske korrelationsmetoder. Den integrative strategi kaldes for ny komparativ/historisk komparation eller ny komparativ politisk økonomi.

Da John Stuart Mill er en af grundlæggerne af engelsk empirisme, den analytiske induktionisme og bidragyder til positivistisk samfundsvidenskab, skulle han og alle hans disciple allerede af den grund være diskvalificeret i kritisk-realistisk forstand og deres komparative metodikker klassificeret som formel, kontekstfri komparation (type 1). Kritisk realisme afskriver dog ikke alt fra den positivistiske tradition, og Mill's komparative metodologi spiller stadig en central rolle i komparativ sociologi, selv inden for kritisk realistisk sociologi. Derfor skal vi se lidt nærmere på de to nye integrative skud på den Mill'ske stamme: Ragin's kvalitative komparative metodik, og Janoski \& Hicks' komparative strategi for politisk økonomi. Har de reformuleret og løst nogle af de problemer, der gælder brugen af Mill's metodologi i komparativ sociologi?

\section{Kvalitativ komparativ metodik}

Charles Ragin (1987) søgte at udvikle en komparativ metodik, der integrerer den kvalitative case-orienterede metodologi og den kvantitative variabel orienterede tilgang og dermed lægge sig på et mellem-niveau, hvor man kan håndtere såvel adskillige cases og et vist antal variable. Dermed løste han op for problemet med 'de få cases' ('the Small N problem') uden at forbryde sig mod case-studiens holistiske tilgang. Den kan bruges til multi-case analyser fra to og opefter, men i praksis med fokus på intervallet 5-50 cases, dvs. et område hvor hverken den kvalitative eller kvantitative metodik slår til (Ragin 1994b:308). Derudover kan den også anvendes på alle typer af multi-case undersøgelser (makro, mezo, mikro) og ikke kun i makro-historiske studier.

Trods den kvantitative udvidelse af 'case-populationen' kalder Ragin alligevel sin metodik for 'kvalitative komparative analyse'. Det skyldes, at han dels opererer med kvalitative faktorer, og dels at analysen skal forklare casene som de helheder (konfigurationer), de anses for at være (Janoski \& Hicks 1994:22 note 8). 
Syntesen af den kvalitative og den kvantitative metodetradition skal ifølge Ragin (1987:82-84) tilfredsstille en række krav, som disse strategier hver for sig kun delvist eller slet ikke indfrier: Den skal kunne sammenholde et stort antal cases; fastholde så meget som muligt af det eksperimentelle designs komparative logik; muliggøre en forenkling af kausale forklaringer og dermed af den erfarede kompleksitet; den skal være både holistisk og analytisk, dvs. at den skal kunne sammenligne helheder som kombinationer eller konfigurationer af dele; og kunne forholde sig til alternative forklaringer.

Ragin formaliserer den kvalitative komparative metodik på grundlag af Boole'sk logik (algebra). I denne logik betyder 'A+B' logisk 'ELLER' (dvs. enten A eller B, eller begge dele) og multiplikationen AB logisk OG (både A og B). Ragin's metodik indebærer et sæt regler, ordnet i en bestemt analytisk fremgangsmåde:

1. Empirisk materiale beskrives i kvalitative faktorer, dvs. i binære værdier (0/1, A/a).

2. Data-matrixen ('sandhedstabellen') konstrueres af de formodede kausale faktorer (A/a, B/b, C/c...) og den afhængige faktor $(\mathrm{Y} / \mathrm{y})$, dvs. ved hjælp af en teoretisk model.

3. Analysen af selve data-materialet starter med at sortere de identificerede cases i sæt (tabel-rækker) efter deres specifikke kausale konfiguration. Man reducerer case-mangfoldigheden til konfigurations-mangfoldighed. De empirisk eksisterende konfigurationer repræsenterer materialets aktualiserede multi-kausale fakticitet (forudsat en gyldig empirisk undersøgelse).

4. De eksisterende konfigurationer analyseres så i forhold til en specifik 'effekt' (kvalitet, binære værdi) af den afhængige faktor (dvs.Y eller y).
Det sker ud fra antagelsen om, at en effekt kan have flere årsager (manifesteret som konfigurationer), men at én kausal konfiguration kun kan have én entydig effektværdi.

5. Analysen af de eksisterende konfigurationer sigter på at minimere deres kompleksitet i to trin: I første omgang sammenholdes de konfigurationer parvis, der er ens, bortset fra en enkelt forklarende faktor og iøvrigt med samme specifik effekt (f.eks. Y). Hvis vi antager, at $A B C D=Y$ og $\mathrm{ABCd}=\mathrm{Y}$, så kan D/d-faktoren elimineres. Den har nemlig ingen betydning for konfigurationens effekt. Ræsonnementet bygger iøvrigt på det klassiske Mill'ske kausalbegreb (hvis ' $x$ ', så enten ' $y$ ' eller ' $Y^{\prime}$ ). Såfremt dette er tilfældet for en række konfigurationer, kan deres antal reduceres tilsvarende og med dem bliver de tilbageblevne konfigurationer mere simple (feks. $\mathrm{ABC}=\mathrm{Y}, \mathrm{Abc}=\mathrm{Y}$, dvs. $A b=Y)$. De har færre faktor-kombinationer end den teoretiske model forudsagde, og dermed eksisterer der en mindre grad af multi-kausalitet i materialet. Minimeringen resulterer i en tabel over de 'primære implikationer' for en given afhængig faktorværdi (her Y). Denne tabel rummer alle empirisk identificerede konfigurationer, der relaterer til en given effekt $(\mathrm{Y})$ inden for en given gruppe af undersøgte cases.

6. Det andet trin i reduktionen af konfigurationer består $\mathrm{i}$ at sammenholde de minimerede konfigurationer (primære implikanter) med de empirisk givne ('fulde') konfigurationer for at se, om nogle af de primære implikanter dækker alle de 'fulde' konfigurationer. Eller sagt på en anden måde, at der er et vist overlap mellem de primære implikationer således, at nogle kan repræsentere alle 
'fulde' konfigurationer. Denne yderligere reducering af de primære implikationer kaldes for en 'reduceret ligning' - i Boole'sk forstand. Hvis vi havde $\mathrm{ABC}, \mathrm{Abc}$ og $\mathrm{Ab}$ som kausale konfigurationer for $\mathrm{Y}$, så kan vores reducerede ligning udtrykkes ved $\mathrm{Y}=\mathrm{ABC}+\mathrm{Ab}$. 'Abc' er nemlig en delmængde af ' $A b$ '.

Denne 'slutligning' for en given effekt kan igen analyseres på forskellige måder:

- Man kan gennemføre en kontrafaktisk analyse, idet man ved en simpel logisk operation kan formulere 'slutligningen', der gælder for den modsatte effekt. Denne operation følger 'De Morgan's lov', der siger, at den kontrafaktiske situation kan formuleres ved at negere den faktiske situation på følgende måde: ' $\mathrm{A}$ ' bliver til 'a' og vice versa; logisk ELLER ('A+B') bliver til logisk OG $\left({ }^{\prime} a b^{\prime}\right)$ og vice versa. I forlængelse af ovenstående ligning for $Y$ bliver den kontrafaktiske ligning: $\mathrm{y}=$ $(a+b+c)(a+B)$.

- Man kan analysere for nødvendige og tilstrækkelige faktorkombinationer (ABC er en tilstrækkelig faktorkombination til at effektuere $\mathrm{Y}$, og det samme er $\mathrm{Ab}$, men 'årsagen' $\mathrm{A}$ er en nødvendig årsag, ikke en tilstrækkelig, idet den altid optræder med andre 'årsager'.

- Man kan omskrive 'slutligningen', så den er nemmere at læse, ved at isolere nødvendige faktorer og identificere ækvivalente faktorer. Feks. kan den reducerede ligning: $\mathrm{Y}=$ $\mathrm{ABC}+\mathrm{Ab}$ omskrives til $\mathrm{Y}=\mathrm{A}(\mathrm{BC}+$ b), hvorved det fremgår at $\mathrm{A}$ er en gennemgående nødvendig årsag til Y.

- $\quad$ Endelig kan man også analysere, i hvilken grad det empiriske materiale er begrænset i teoretisk forstand ('the problem of limited diversity'), problemet med kontradiktoriske effekter (både-og effekter for samme kausale konfiguration), samt spørgsmålet om alternative forklaringer (Ragin 1987 kap. 6-7).

Alt i alt kan man medgive Ragin, at den kvalitative komparative analyse imødekommer de fem krav, han stiller til en syntetisk komparativ strategi: Den kan håndtere et stort antal cases og komplekse kausale samspil, reducere den empiriske kompleksitet til enklere forklaringer, analysere cases både som helheder (konfigurationer) og dele, samt vurdere konkurrerende forklaringer (Ragin 1987:121-123).

\section{Kritik af kvalitativ komparativ metodik}

Den deterministiske kausalitetsopfattelse er blevet kritiseret for at invalidere Ragin's analyseapparat (King et.al. 1994). Ragin anfører, at han netop bevidst undgår at anskue konkrete cases som 'fejl' og 'tilfældigheder', men ser dem som fænomener, der kræver en forklaring. På den anden side kan hans kausalitetsbegreb modificeres i stokastisk retning, hvis man med Ragin betegner konfigurationer, hvor alle cases har samme effekt, som havende determinerende kausalitet; konfigurationer, hvor mindst $50 \%$ af casene har samme effekt, som havende sandsynlig kausalitet; og konfigurationer, hvor under $50 \%$ af casene har samme effekt, som havende en mulig kausalitet (Ragin mfl. 1993).

En anden kritik går på, at den kvalitative komparative analyse ikke vægter forklaringsværdien af de enkelte faktorer, således som det er muligt at gøre i regressionsanalyser. Ragin (1997:37) finder ikke denne kritik relevant, da analy- 
semetoden netop bygger på, at faktorerne optræder i 'kausale stier' ('causal pathways') og sjældent alene. Men man kan dog vægte forklaringsværdien af disse 'kausale stier' ved at sammenholde antallet af cases, de forklarer.

Den rent kvalitative 'binære' virkelighedsbeskrivelse, der kendetegner kvalitativ komparativ analyse, har også været et tilbagevendende problem. Ragin har senest forsøgt at komme bort fra denne rent kvalitativ virkelighedsbeskrivelse ved at udforme en 'fuzzy logic', der muliggør en variabel (kvantitativ) beskrivelse af forskellige kvalitative konfigurationer, herunder idealtyper (Ragin undated; Kvist 1999 og i dette nummer). Dermed sikres en stærkere empirisk operationalisering af kvalitative begreber og analyser af kvantiteters omslag i kvalitative forandringer.

Endelig hævder Janoski \& Hicks (1994:16-17) med en vis ret, at Ragin i praksis 'glemmer' den interne, holistiske case-analyse. I princippet fastholder Ragin dog enkel-case analysen som vigtig også for multi-case komparationen.

Selvom Ragin's metodik fremtræder som overvejende positivistisk inspireret med aner tilbage til Mill's 'sammenfaldsmetode' og 'afvigelsesmetode (Janoski \& Hicks 1994:16), er metodikkens videnskabsfilosofiske grundlag lidt uklar. Den afviger på tre måder fra den empiriskanalytiske videnskabsfilosofi:

- Man anvender et multi-kausalt forklaringsbegreb, der forudsætter, at effekter kan have mange forklarende faktor-kombinationer, dvs. kombinationer der hver i sær er tilstrækkelige til at forklare effekten; de såkaldte 'stier' ('pathways').

- Disse faktor-kombinationer kan bestå af nødvendige og/eller tilstrækkelig faktorer af forskellig forklaringsværdi.
- Man kan kun reducere den empiriske kompleksitet i dens kontekstualitet, idet man fastholder, at de enkelte årsagsfaktorer optræder i sammenhæng og derfor må tolkes i sammenhæng. Inden for to forskellige årsagssammenhænge kan samme faktor antage forskellig karakter og alligevel medvirke til at forklare samme effekt. 'A' såvel som 'a' kan medvirke til at fremkalde ' $Y$ ', men kun i forskellige årsagskonfigurationer.

Disse principper passer som fod i hose til en kritisk realistisk komparativ analyse, da de kan bruges til at identificere kausale mekanismer i deres kontekst. Problemet er blot, at Ragin's årsagsbegreb (årsags-konfigurationen) ikke rummer nogen skelnen mellem generative mekanismer og disse mekanismers kontekstuelle konditionalitet. De kausale konfigurationer kan både rumme generative kræfter/mekanismer, alternative generative årsager, kontekstuelle betingelser samt generative årsager til sådanne betingelser. Ragin's komparative metodik kan derfor klassificeres som formel, kontekstuel komparation (metodologi af type 2).

\section{Nyere politisk-økonomisk komparation}

Janoski \& Hicks (1994) forsøger også at opstille en integreret komparativ strategi med relevans for politisk-økonomiske studier. Med 'politisk økonomi' tænkes på strukturelt orienterede studier af lande, deres institutionelle systemer samt klasse og interesse-organisationer, men ikke på egentlige politisk-økonomiske mikro-fænomener.

Ifølge Janoski \& Hicks repræsenterer Ragin's analyse godt nok en fornyelse af komparativ metodik, men den kvalitative komparation forbliver en form for eks- 
tern analyse af flere cases og negligerer den interne, dynamiske analyse af de enkelte cases. Janoski \& Hicks (1994:7-13) foreslår en integreret komparativ/historisk strategi, der forsøger at komme bagom 'eksterne' (formelle) empiriske sammenhænge og forklare disse sammenhænge ved 'interne' (substantielle) strukturer og processer. Dermed forholder de sig til 'sorte kasse problemet' i komparativ positivistisk samfundsforskning, hvor man konstaterer regelmæssigheder (korrelationer) uden at kunne forklare disse regelmæssigheder på en meningsfuld måde gennem sociale processer (Goldthorpe 1997:13).

Strategien består af en række metoder, der ordnes successivt i en række faser, herunder to tidsforskudte analyser i form af ekstern og intern analyse. Med ekstern analyse tænkes på en komparativ analyse af fænomenet landene (casene) imellem (en formel, udvendig sammenligning af casene). Med intern analyse menes en subnational analyse af fænomenet i det enkelte land (case), varierende over tid (en indvendig analyse af de enkelte systemers forandringsprocesser). Konkrete metoder kan rumme elementer af såvel ekstern som intern analyse, f.eks. tidsseriestudier (intern analyse), tværsektoranalyse (ekstern analyse) og kombinationsanalyse ('pooled analysis'; intern og ekstern analyse). Den samlede komparative forskningsstrategi deles op i syv faser (Janoski \& Hicks 1994:8-9):

1. Udvælgelse af forskningsproblem og teori på basis af abduktion, kundskabssociologi, teoretisk tradition, litteratursøgning og besøg af lande, arkiver $\mathrm{mm}$.

2. Udarbejdelse af den første forskningsdesign: Indledende ekstern analyse med baggrund i landevalg ud fra ligheder og forskelle (Mill'ske, Boole'ske, og statistiske metoder) og valg af tidsperiode ud fra betydningsfulde begivenheder.

3. Data-indsamling (opbygning af datasamlinger om de enkelte variable i hvert land med et vågent øje til definitoriske forskelligheder, systematisk dataindsamling, systematisk opsamling af informationer fra feltarbejdet).

4. Udarbejdelse af den anden forskningsdesign: intern analyse på basis af arkiv- og dokumentariske studier, sekundær historie, feltinterviews, tidsserier og tvær-sektoriel analyse, samt tværsnitsundersøgelser og folketællinger.

5. Reformulering af teori ud fra en refleksion over begrebernes ækvivalens for de enkelte lande, og ud fra de enkelte lande-modeller.

6. Tilpasning af teorien i den interne analyse til den overordnede teori i den eksterne analyse ved at tilpasse intern teori til den endelige teori, og gentag den eksterne analyse.

7. Afrapportering.

Janoski \& Hicks lægger altså op til en pluralistisk strategi, idet den komparativt baserede eksterne analyse af lande kombineres og uddybes med en multimetodisk intern analyse af de eksternt beskrevne sammenhænge. I begge tilfælde kan man anvende såvel en statisk (synkron) eller dynamisk (diakron) komparativ analysestrategi.

Deres metodik minder om Skocpol \& Somers' kausale komparation, men den går videre. Den kan siges at rumme identifikationen af begivenheder og deres formelle årsager (den eksterne analyse); derefter forsøg på at forklare denne sammenhæng realt, strukturelt og dynamisk (den interne analyse af den enkelte case); og endelig en kontrasterende undersøgelse af korrespondancen mellem intern substantiel teori og ekstern formel teori. 
Janoski \& Hicks' forskningsstrategi stemmer godt overens med den kritiske metodepluralisme, der forfægtes af Danermark-gruppen med afsæt i Sayer's to metodestrategier. Deres interne analyse modsvarer til en vis grad den kritisk realistiske intensive analyse, men Janoski \& Hicks nøjes ikke med kvalitative analyser. Omvendt tænker de mere i komparative case-studier vedrørende eksterne analyser, men det skyldes nok primært, at de beskæftiger sig med makro-orienterede politisk-økonomiske analyser.

I et kritisk realistisk perspektiv synes Janoski \& Hicks største problem at være deres manglende eksplicitte kontekstualisering i deres interne og eksterne analyser. De nævner godt nok, at lande ofte har indbyrdes forbindelser, og at de i givet fald må medtages i den eksterne undersøgelsesfase, men mere bliver det ikke til. Dermed løber de ind i det såkaldte 'Galton's problem', til trods for at de nævner det som del af den komparative sociologiske problematik (Janoski \& Hicks 1994:2). Galton's problem rejser spørgsmålet, om ligheder imellem samfund ('udvendige' forhold) skyldes endogene (interne) eller eksogene (relationelle) årsager (se Goldthorpe 1997:9). Janoski \& Hicks mangler øjensynligt en teori om (substantielle) relationer mellem landene (casene) og en analyse af disse relationer i forbindelse med den interne og eksterne analyse.

At den teoretisk-empiriske analyse kan fremmes gennem abduktive og retroduktive øvelser, er noget, som Janoski \& Hicks delvist medreflekterer i den angivne komparative forskningsstrategi (abduktion i fase 1; den teoretisk-empiriske frem og tilbageføring $i$ fase 5 og 6). Men de mangler den transcendental kausalanalyse i deres teoretiske og metodologiske tilgang.

Alt i alt kan Janoski \& Hicks' komparativ/historiske metodologi karakterise- res som en strategi, der kombinerer formel og substantiel generaliserende (dekontekstuel) komparation (type 1 og 3) med lidt formel, kontekstuel komparativ metodologi (type 2). Men de integrerer ikke deres komparative metodikker i en og samme komplekse, substantielle komparation (type 4).

\section{Det andet komparative paradoks}

Kritisk realisme tager som nævnt afsæt i egne ontologiske overvejelser og ikke i positivismens epistemologiske udgangspunkt. Derfor var det nærliggende at spørge, om den kritiske realisme kunne bidrage til fremme af en alternativ komparativ sociologiske metodologi, men det viste sig, at kritisk realistisk sociologi ukritisk trak på den eksisterende komparative tradition. Kan man det? Kan denne traditions metodikker uden videre inkorporeres i kritisk realistisk samfundsforskning?

Pilen peger i retning af et nej. Ud fra de centrale dele af den komparative tradition, som vi har set på, har den været præget af empirisk-analytisk videnskabsteori. De manglende overvejelser omkring generative mekanismers substantielle og transcendentale karakter og/eller kontekstualisering er centrale punkter i ovenstående kritik af de nævnte komparative metodikker.

Denne konstatering indebærer et nyt paradoks: På den ene side prioriteres komparation som en væsentlig metodik i kritisk realistisk sociologi, men den findes ikke hverken i efterkrigstidens komparative tradition eller i den nye kritisk realistiske sociologi. Det næste spørgsmål er derfor, om og hvordan en kritisk realistisk komparativ metodologi kan og bør udformes?

I dag står kritisk realistisk sociologi for mig at se over for to substantielle komparative udfordringer: 
- at formulere en komparativ metodik, der kan levere kontekstuelt generativt kausale analyser, samt

- at forklare hvordan komparative metoder kan blive relevante og slagkraftige analyser i og af en verden, der bliver stadig mere internationaliseret og globaliseret.

\section{Den generative-kausale udfordring}

Den første udfordring til kritisk realistisk metodeudvikling berører 'black box' problemet i komparativ sociologi, og en mulig og praktisk løsningen ligger for mig at se i at 'abducere' Ragin's kvalitative komparative analyse.

Ragin forsøger eksplicit at skabe en metodisk brobygning mellem kvalitativ og kvantitativ metodik. Han metodik bygger på en kausalitetsopfattelse, der muliggør såvel kontekstualisering som alternativ teori-formulering og -afprøvning (intern validitet) samt gyldighedsområde (eksterne validitet). Dens komparative empiriske grundlag kan basere sig på tværsnits- eller forløbsstudier. Dens teoretiske modelkonstruktion kan udvikles gennem abduktion og retroduktion. Ragin $(1994 a: 47,57)$ bruger faktisk betegnelsen 'retroduktion' for samanalysen af deduktivt udledte modeller (analytical frames) og induktivt afledte 'billeder' (images). Han bruger ikke begrebet snævert til kun at betyde 'transcendental argumentation'. I den forstand forudsætter Ragin's brug af retroduktions-begrebet en forudgående induktiv og deduktiv analyse. Begrebet abduktion nævner Ragin dog slet ikke.

Med Ragin's metodik tvinges man hele tiden til spørge til den empiriske gyldighed af teoretiske forklaringer, og den udfordrer dermed den form for retroduktive analyser, der kun abstraherer fra det faktiske og empiriske domæne og ikke også konkretiserer de abstrakte analyser. Det gør den ved at forlange empirisk gyldige årsagsforklaringer. Men Ragin begrænser sig til at søge efter flere forklarende faktorer og mere differentierede virkninger, og han overser til en vis grad mulighederne for at bruge den kausale kompleksitetsforståelse til at differentiere disse konfigurationer i mere præcise årsags- og effekt-relationer.

Man kan alt i alt tage skridtet fuldt ud og rekontekstualisere (abducere) Ragin's multi-kausale metodik væk fra dens Mill'ske empiricisme og over i retning af kritisk realistisk komparation. En sådan omfortolkning vil indebære, at man blandt andet skelner mellem:

- $\quad$ operative og ikke-operative generative mekanismer (forklarende empiriske faktorer til forskel for passive, transcendentale mekanismer),

- andre operative generative mekanismer (alternative empiriske, forklarende faktorer),

- $\quad$ operative betingende virkninger af generative mekanismer (empiriske konditionaliteter), samt

- operative og ikke-operative betingende generative mekanismer (empiriske generative mekanismer af faktiske konditionaliteter ).

Med den sidstnævnte refortolkning vil man blandt andet kunne bruge kvalitativ komparativ analyse til at undersøge en given empirisk sammenhæng mellem en aktuelt virkende generativ mekanisme og dens effekt(er) samt alternative forklarende mekanismer. Derudover kan man underkaste den konstaterede kausale relation en kontekstuel analyse af dens begrænsning/betingning/bundethed, dvs. betragte den kausale relation som enten betinget eller som 'effekt' af de kontekstuelle faktorer. I sidstenævnte tilfælde lægges der op til en endnu dybere 
kausalanalyse. Den kausale relations konditionalitet bliver under alle omstændigheder tydeliggjort, og man kan fundere videre over generative mekanismer, der forklarer de(n) generative mekanismer og/eller deres kontekstualitet - en analytisk proces, der kan foregå gennem retroduktive analyser i snæver (transcendental) forstand eller gennem hele batteriet af induktive, deduktive, abduktive og retroduktive analyser i Danermark'sk forstand.

Endelig er det værd at gentage, at Ragin's metodik udmærket kan bruges diakront i såkaldte interne, proces-orienterede enkel-case studier: casen omdefineres da til case-enheder, der varierer over tid. Dermed åbnes der op for proces-orienterede, generative analyser.

\section{Globaliseringens udfordring}

Den anden udfordring udspringer af det helt grundlæggende spørgsmål om, hvordan den sociale virkelighed må være konstituteret for, at man kan bruge komparativ sociologisk metodik. Tillægsspørgsmålet er, om dette krav kan indfries i et kritisk realistisk perspektiv.

Svaret på hovedspørgsmålet indebærer traditionelt, at casene skal være uafhængige af hinanden og kommensurable, for at de kan sammenlignes. Hvis de er forbundne, kan man ikke ud fra beskrivelser af de forskellige cases egendynamik slutte sig til, hvad der måtte forklare de forskelle og ligheder, man måtte ønske at forklare. Hvis de er inkommensurable, kan de ikke sammenlignes meningsfuldt (Hvad er højest? Rundetårn eller et tordenskrald? Bredsdorff 1998:73).

Begge disse problemer kan til en vis grad håndteres inden for kvalitativ komparativ analyse. Afhængighedsrelationer kan medtages som beskrivelse af casenes ydre relationer, og kommensurabilitet må fortolkes kontekstuelt, hvorved de sammenlignede fænomener skal ligestil- les i forhold til den kontekst, de udspringer af (kontekstuel ækvivalens).

Ragin mfl. (1993) viser således, hvordan en multi-case analyse af indiske landsbyer og deres sociale kohæsion (Wade 1988) kan undersøges ud fra to eksternt kontekstuelle teorier. Wade forklarer social kohæsion ud fra landsbyernes økologiske position (i forhold til adgang til vand), mens Ragin mfl. anlægger en teori om inter-gruppe konflikter på landsbyproblemet. Ragin demonstrerer, at hans kvalitative komparative analyse er Wade's analyse overlegen, blandt andet fordi den kan håndtere 41 cases og anlægge en bredere tilgang, der muliggør en prøvning af begge teorier. Wade's teori gælder i visse tilfælde, men er mere begrænset end antaget, mens Ragin's sociale konflikt teori kan forklare flere og også 'anomaliske' tilfælde i forhold til Wade's teori. Ragin's analyse indbefatter dog ikke interne, diakrone studier af enkeltlandsbyer.

Mens Janoski \& Hicks nøjes med at påpege problemet med interaktionen mellem casene (det føromtalte 'Galton problem') er Skocpol's pointe i hendes kritik af Barrington Moore's forklaring af politiske moderniseringsprocessers forskelligartede udfald netop, at sociale revolutioner ikke kun forårsages af endogene forhold, men også af staters internationale relationer med krigen som den helt centrale historiske begivenhed. Men Skocpol nåede ikke selv at formulere en teori, der forbandt staters socio-politiske udvikling med internationale politiske relationer. Tværtimod bevægede hun sig væk fra det internationale og over i en indadrettet historisk-sociologisk retning (Hobden 1998 kap. 4).

I dag vedrører Galton's problem internationaliseringens og globaliseringens indvirkning på de nationalstatslige samfundssystemer. I en diskussion af europæiseringens metodologiske problema- 
tik argumenterer Ebbinghaus (1998), at den komparative metodik længe har anlagt et endogent perspektiv på (makro)genstandsfeltet, men at den ikke principielt er afskåret fra at kunne bruges i studiet af internationale strukturer og processer, herunder den europæiske integrationsproces. Endogen forklaring står her i modsætning til relationel forklaring, og ikke til eksterne og interne forklaringer i Janoski \& Hicks forstand.

Ebbinghaus foreslår en multi-centreret og niveau-differentieret strategi for studiet af internationale relationer. En sådan strategi vil gøre det muligt at foretage en kompleks analyse af de mange forskellige afhængighedsrelationer, der findes i de situationer, hvor mange aktører opererer på mange system-niveauer.

I et kritisk realistisk perspektiv vedrører Galton-problemet grænsedragningen mellem et objekt (dets struktur) og dets omgivelser (kontekst). Generative mekanismer er bundet op på en struktur og dermed strukturens objekt. Alternative forklaringer ligger derfor også inden for dette objekt og dets mange mekanismer. Betingelser for disse mekanismer er lokaliseret uden for dette objekt og udgør dermed dets omgivelser. Men såfremt objektet og omgivelserne interagerer og genererer en fælles struktur, skifter objektet karakter, og omgivelsesbetingelserne bliver en del af strukturen og får dermed en anden kausal status. Det før så åbne sociale system lukkes til en vis grad.

Denne fortolkning kræver en tydeliggørelse af begrebet kontekst, idet kontekst bruges i flæng om en masse forskellige forhold: kausalforklaringer, objekt-interne betingelser for alle nævnte eller relevante kausalforklaringer, eller irrelevante objekt-eksterne betingelser. Det gode ved Ragin's metodik er som tidligere nævnt, at den kan gøre denne problematik synlig og håndterlig metodisk. Dermed kan den fungere som en jordforbindelse til transcendentale envejs-analyser, der forbliver rene gætterier, så længe de ikke også konkretiseres og valideres empirisk.

Det store spørgsmål melder sig nemlig igen og igen: Fører den kritiske realisme's transcendentale karakter over i den modsatte grøft af positivismens 'epistemiske fejltagelse' i form af en 'ontologisk fejltagelse'?

Denne fejltagelse opstår, når man sætter lighedstegn mellem vores grundlæggende opfattelse af verden (ontologien) og den virkelige verden uden for os selv. Den snerper hen i retning af postmoderne konstruktivisme, blot på et højere abstraktionsniveau, fordi erkendelsesprocessen i kritisk realisme underordnes ontologien. Hvis man ikke også kritisk reflekterer over den kritisk realistiske ontologi, bliver man bundet op på nogle forestillinger, der måske ikke passer i virkeligheden - med den langsigtede konsekvens, at kritisk realistisk forskning stagnerer metodologisk og teoretisk.

\section{Konklusion}

Denne artikel leder frem til fem konklusioner. For det første er kritisk realisme en oplagt forbundsfælle i formuleringen af den komparative metodiks erkendelsesmæssige og metodologiske præmisser. For det andet har kritiske realister endnu ikke udviklet en genuin komparativ metodik til trods for, at komparation er en højt prioriteret metodik (paradoks 1). For det tredje henviser man til den komparative tradition, uden at man underkaster den en kritisk realistisk videnskabsteoretisk vurdering. En sådan vurdering af centrale komparative metodikker viser, at disse metodikker bygger på en positivistisk og ikke en kritisk realistisk videnskabsfilosofi (paradoks 2). Dog rummer den nyere komparative sociologiske tradition for det fjerde (mindst) to metodikker og metodestrategier, der kan refortolkes (abduceres) fra den dominerende 
Mill'ske tradition og gives nyt liv i et kritisk realistisk perspektiv. Det gælder Charles Ragin's kvalitative komparative metodik og Janoski \& Hicks' komparative/historiske strategi. Begge metodologier har en lang række kvaliteter og potentialer, der gør dem til oplagte afsæt for udviklingen af en komparativ metodik i kritisk realistisk sociologi. Den femte og sidste konklusion er derfor, at sociologiens komparative (arve)gods kan bidrage til at udfylde det komparativ-metodiske hul i kritisk realistisk samfundsforskning.

\section{Noter}

1. Metodologi forstås her som læren om empiriske og analytiske metoder; metodik som et sæt af metoder; metodisk strategi som en successiv brug af metoder; epistemologi som læren om hvordan vi erkender virkeligheden; og ontologi som læren om hvordan virkeligheden er beskaffen. Tak i øvrigt til anonym referee for konstruktiv kritik.

2. I forhold til klassisk sociologisk komparation hos Marx henvises til Brodersen (1993), for Weber i kritisk realistisk perspektiv se Ekström (1992), og Durkheim er behandlet i Jens Tonboe's kommentar i dette nummer af Dansk Sociologi.

3. „The Method of Agreement stands on the ground that whatever can be eliminated, is not connected with the phenomenon by any law. The Method of Difference has for its foundation, that whatever cannot be eliminated, is connected with the phenomenon by a law." (Mill 1862 vol I:430).

4. Inden for tværnational komparativ sociologi blev Prezeworski \& Teune (jfr. Goldthorpe 1997:2) berømte for deres insisteren på, at komparativ analyse så vidt muligt skulle søge at erstatte system-navne (USA, Danmark mm) med faktorer/variable: "In the context of theory, names of systems are interpreted as residua of variables - that which is not accounted for by a theory. Within the context of measurement, systems are treated as determinants of the validity of inferences leading to measurement statements. The implications of these positions are that specific systems are treated as labels for unspecified factors rather than as limits of generality and that equivalence of measurement statements is treated as a matter of the validity of inferences rather than of the nature of the indicators (1970:132)

5. Den komparative logik bag denne metode er ifølge Janoski \& Hicks (1994:23 note 10) begrundet i 'Afvigelsesmetoden', men jeg vil nu hellere kalde den 'Uenighedsmetoden' (Method of Disagreement): de to cases er kontraster, deres forskellighed begrundes i deres holistiske kontrast, og de implicerer derfor ikke et design af 'Most Different Systems'. Svagheden ved metoden er, at man i sin iver efter at imødegå generalisering og kausale forklaringer ender op i 'en form for deskriptiv holisme' (Skocpol \& Somers 1980:192). Man afskriver sig fra eksplanatorisk argumentation ud over, hvad der i de ofte detaljerede kronologiske redegørelser implicit fremstår som en slags 'genetisk determinisme'. Man dynger analysen til med detaljer og undgår dermed at eksplicitere en forklaring af historie-fortællingens forløb og konsekvenser. Historien fortæller sig selv, den danner sin egen verden, men derved kan den også let blive brugt eller misbrugt i enhver sags tjeneste, da der er noget for enhver smag.

\section{Litteratur}

Archer, Margaret 1995: Realist social theory: the morphogenetic approach. Cambridge: Cambridge University Press.

Archer, Margaret et.al. (eds) 1998: Critical realism. Essential readings. London: Routledge.

Bhaskar, Roy 1998 [1997/1975]: "Philosophy and scientific realism". In: Archer, Margaret (1998) Critical realism. Essential readings. London: Routledge, pp.16-47.

Bonnel, Victoria E. 1980: "The Uses of Theory, Concepts and Comparison in Historical Sociology". Comparative Studies in Society and History, 22:2, pp. 156-173.

Bredsdorff, Nils 1998: “Om den komparative metode i forvaltningsvidenskaben". Politica Nr. 1, s. 73-93.

Brodersen, Arvid 1993: "Komparativ sosiologi“. Sosiologi i dag, 23:4, s. 3-15. 
Danermark, Bert mfl. 1997: Att förklara samhället. Lund: Studentlitteratur.

Djurfeldt, Göran 1996: Boström och kaminen. En introduktion till realistisk vetenskapsteori. Lund: Arkiv förlag.

Ebbinghaus, Bernhard 1998: "Europe through the Looking-Glass: Comparative and Multi-Level Perspectives".Acta Sociologica, 41 pp.301-313.

Ekström, Mats 1992: "Causal Explanation of Social Action". Acta Sociologica , 35, pp.107-122

Flyvbjerg, Bent 1992 [1991]: Rationalitet $\mathcal{E}$ Magt. Bd. I: Det konkretes videnskab. Odense: Akademisk Forlag.

Goldthorpe, John H. 1997: “Current Issues in Comparative Macrosociology: A debate on methodological issues". Comparative Social Research Vol. 16 pp. 1-26.

Hobden, Stephen 1998: International Relations and Historical Sociology. Breaking down boundaries. London: Routledge.

Janoski, Thomas \& Alexander M. Hicks 1994: "Methodological innovations in comparative political economy: an introduction". In: Janoski, Thomas \& Alexander M. Hicks (eds) The Comparative Political Economy of the Welfare State. Cambridge: Cambridge University Press, pp. 1-27.

Johansson, Björn \& Martin Lind 1999: "Bunge vs. Bhaskar. Några kritiska reflektioner kring "nya" teoriers originalitet". Sociologisk forskning 2/99, s.82-95.

King, Gary et.al. 1994: Designing Social Inquiry. Scientific Inference in Qualitative Research. Princeton: Princeton University Press.

Kirkeby, Ole Fogh 1990: "Abduktion". I: Andersen, Heine (red) Videnskabsteori og metodelære, bind I. København: Samfundslitteratur, s. 119-147.

Kvist, Jon 1999: "Welfare Reform in the Nordic Countries in the 1990s: Using Fuzzy-set Theory to Assess Confor- mity to Ideal Types". Journal of European Social Policy, 9:3, pp. 231-252.

Mill, John Stuart 1862 [1843]: A System of Logic, Ratiocinative and Inductive. Vol. I-II London: Parker, Son, and Bourn, West Strand.

Pawson, Ray 1989: A Measure for Measures. A manifesto for empirical socio$\log y$. London: Routledge.

Pennings, Paul et.al. 1999: Doing Research in Political Science. An introduction to comparative methods and statistics. London: Sage Publications.

Przeworski, Adam \& Henry Teune 1970: The Logic of Comparative Social Inquiry. New York: Wiley Interscience.

Ragin, Charles 1987: The Comparative Method. Moving Beyond Qualitative and Quantitative Strategies. Berkeley: University of California Press.

Ragin, Charles 1994a: Constructing Social Research. The Unity and Diversity of Method. London: Pine Forge Press.

Ragin, Charles 1994b: "Introduction to qualitative comparative analysis". In: Janoski \& Hicks (eds) The Comparative Political Economy of the Welfare State. Cambridge: Cambridge University Press, pp. 299-319.

Ragin, Charles 1997: "Turning the tables: How case-oriented research challenges variable-oriented research". Comparative Social Research, Vol. 16, pp.27-42.

Ragin, Charles (undated): " Comparative Methodology, Fuzzy Sets, and the Study of Sufficient Causes". Mimeo, published in APSA-CP's Comparative Politics Newsletter, vol. 9(1).

Ragin, Charles mfl. 1993: "Mellom kompleksitet og generalisering: En kvalitativ komparativ analys av Village Republics". Sosiologi i dag Nr. 3/1993, s.67-87.

Sayer, Andrew 1992 [1984]: Method in Social Science. A Realist Approach. London: Routledge. 
Skocpol, Theda \& Margaret Somers 1980: "The Uses of Comparative History in Macrosocial Inquiry". Comparative Studies in Society and History, 22:2, pp.174-197.

Wad, Peter 2000a: "Mellem enhedsvidenskab og flerhedsvidenskab". Grus nr. 60 s. 5-16.
Wad, Peter 2000b: "Kritisk realisme". Grus nr. 60 s. 53-68.

Wade, Robert 1988: Village Republics: Economic Conditions for Collective Action in South India. N.Y: Cambridge University Press. 